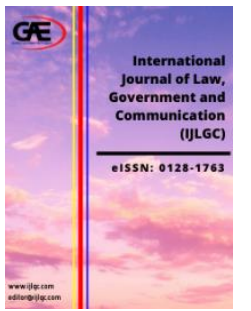

\author{
INTERNATIONAL JOURNAL OF LAW, \\ GOVERNMENT AND COMMUNICATION \\ (IJLGC) \\ www.ijlgc.com
}

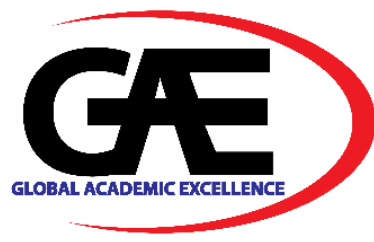

\title{
RIGHT OF MIGRANT WORKERS TO OCCUPATIONAL HEALTH AND SAFETY UNDER MALAYSIA LAWS
}

\author{
Aminuddin Mustaffa ${ }^{1}$, Cherifi Noura ${ }^{2 *}$, Md. Mahbubul Haque ${ }^{3}$ \\ 1 Faculty of Law \& International Relations, Sultan Zainal Abidin University, Malaysia \\ Email: aminuddinm@unisza.edu.my \\ 2 Faculty of Law \& International Relations, Sultan Zainal Abidin University, Malaysia \\ Email: maitrecherifi85@gmail.com \\ 3 Faculty of Law \& International Relations, Sultan Zainal Abidin University, Malaysia \\ Email: mahbubh@unisza.edu.my \\ * Corresponding Author
}

\section{Article Info:}

Article history:

Received date: 04.10.2021

Revised date: 21.10 .2021

Accepted date: 10.11 .2021

Published date: 01.12.2021

\section{To cite this document:}

Mustaffa, A., Noura, C., \& Haque, M. M. (2021). Right Of Migrant Workers

To Occupational Health And Safety Under Malaysia Laws. International Journal of Law, Government and Communication, 6 (26), 48-60.

DOI: $10.35631 /$ IJLGC.626005.

This work is licensed under CC BY 4.0

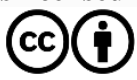

Abstract:

The migration of people to other countries in search of employment is a common phenomenon that has occurred throughout history. While migration is a positive and empowering experience, migrant workers can be vulnerable to human rights violations. In this context, international laws have provided the international legal framework on the rights of migrant workers. Among the fundamental rights of migrant workers is the right to occupational health and safety within which a worker is expected to perform his job. This paper aims to examine the right of migrant workers to occupational health and safety in light of international standards and Malaysian laws. It adopts qualitative research of doctrinal and comparative nature. It will examine the adequacy of current laws in recognizing and protecting the rights of migrant workers to occupational safety and health with reference to the standards set by the international instruments. The paper also attempts to identify factors that contributed to the high number of occupational accidents. The paper concludes that the current Malaysian laws provide a specific legal framework that aims to protect the right of migrant workers to occupational health and safety. However, non-compliance with law requirements and lack of enforcement has contributed to the high number of occupational accidents. In conjunction with that, the paper provides recommendations towards improving the Malaysian legal framework on occupational health and safety.

\section{Keywords:}

Occupational Health and Safety, Migrant Workers, Malaysian Law, International Standards 


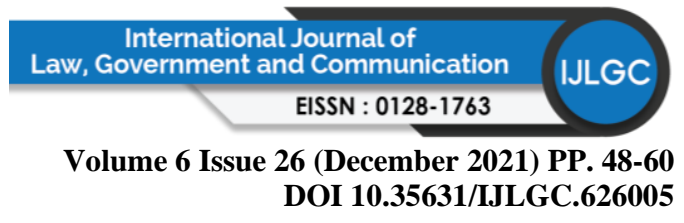

\section{Introduction}

Migration is a human movement from his usual residence to another place, whether within a country or across an international border, for various reasons. It is a positive global phenomenon that affects multiple countries around the world. According to the report, there are currently 272 million migrants globally, which account for 3.3 of the worldwide population (International Organization for Migration, 2020). The report disclosed that Malaysia is one of the most popular destinations for migrant workers in East Asia. The World Bank estimated that between 2.96 to 3.26 million migrant workers worked in Malaysia in 2017(World Bank, 2019). This fact has made Malaysia the sixth-largest migrant-receiving country in East Asia. Another report estimates a total of 3.85 to 5.3 million migrant workers in Malaysia in 2018, including undocumented workers (Yusof Ishak Institute, 2018). The statistic also reveals that Indonesian workers constitute the majority of foreign workers (39\%), followed by Nepali workers (24\%), Bangladeshi workers (14\%), and the rest are combined from many other countries (Ministry of Economic Affairs, 2020).

Lack of economic opportunities is one of the primary motives that drive people to migrate, looking for better employment and career advancement. Unfortunately, not all of them manage to pursue their dream. The reports disclosed that some labour migrants had been subjected to mistreatment and violation of rights. One of the common issues regarding the mistreatment of migrant workers is the violation of their right to occupational health and safety. Migrant workers are always involved in what is known as 3-D jobs (dirty, dangerous, and demanding). Due to the nature of these types of jobs, migrant workers are considered a high-risk group, particularly in safety and occupational health matters. Unfortunately, their right to a safe workplace and occupational health has always been ignored and taken for granted due to their vulnerable position. In fact, some of them are forced to work in risky, dangerous, and unsafe working conditions without proper training, lack of protective equipment, and lack of professional supervision. This has resulted in the high number of occupational injuries and fatalities among migrant workers recorded worldwide. For example, the International Labor Organization (ILO) reported that nearly 2.3 million occupational fatalities occurred worldwide in 2014 (International Labour Organization, 2019). There are various factors that contributed to the high number of occupational incidents among migrant workers, such as inherent risks in the jobs themselves and the lack of training and protection for immigrant workers.

This paper will examine the right of migrant workers to occupational health and safety. The first part briefly highlights the background relating to the issue of occupational health and safety faced by migrant workers. The second part examines the position of the international legal framework on this right. The third part analyzes Malaysian law on the right of migrant workers to occupational safety and health. It will also discuss issues surrounding this right faced by migrant workers in this country. The last part will conclude the discussion and provide recommendations to address this particular legal issue.

\section{Methodology}

This paper adopts qualitative research of doctrinal and comparative analysis. It will examine the adequacy of current laws in recognizing and protecting the rights of migrant workers to occupational safety and health with reference to the standards set by the international instruments. The research will fundamentally involve the critical analysis of material from both primary and secondary sources. Reference will be made to the relevant international instruments as well as local statutes, such as the Workmen's Compensation Act1952, 


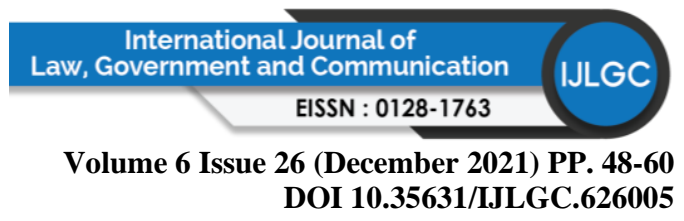

Employment act 1955, immigration act1963, the Universal Declaration of Human Rights, the Human Rights of All Migrant Workers and Members of Their Families and others. On the other hand, references will also be made to secondary sources to obtain relevant information and data on this subject. Apart from that, this paper also adopts a comparative analysis method to identify weaknesses or shortcomings in the existing Malaysian laws on this subject.

\section{Right To Occupational Health under International Law}

International Legal instruments promote and emphasize the protection of the rights of migrant workers. Reference to these instruments discloses various provisions provided under different international instruments concerning the rights of migrant workers. These instruments have laid down international standards and legal frameworks on the protection of the rights of migrant workers. These also serve as a reference and benchmark for all legal systems across the world.

The right of a worker to occupational health and safety is considered a fundamental right, which must be consistently upheld. Provisions emphasizing the importance of these rights can be found in various international instruments. For example, Article 23 of the Universal Declaration of Human Rights (UDHR) guarantees the right of everyone the right to work, to free employment, to just and favourable conditions of work, and to protection against unemployment (United Nations, 2016). The term "everyone" in the provision gives a clear connotation that this right is accorded to all workers, including migrant workers, regardless of their position, gender, race, ethnicity, status, and others. In addition, Article 7(a) of the UDHR recognizes the equal right of women and men to just and favorable work conditions, including workers' rights to safe and healthy working conditions. In other words, the UDHR evidently guarantees the right of migrant workers to occupational health and safety without distinction of any kind.

Apart from that, the right of everyone to occupational health and safety is also guaranteed by the Human Rights of All Migrant Workers and Members of Their Families (ICRMW). The convention provides several specific provisions relating to the occupational health and safety of migrant workers at the workplace. For example, Article 70 of the Convention mentions the duty of the States Parties to take measures to ensure that working and living conditions of migrant workers and members of their families in a regular situation are in keeping with the standards of fitness, safety, health, and principles of human dignity. As regards the safety and health aspect, the ICRMW emphasizes that shall be no discrimination or unequal treatment between local and migrant workers. Article 25(1) demands the state parties take all necessary measures to ensure that migrant workers shall enjoy treatment not less favourable to the local workers in respect of safety and health and conditions of work. In the event of any occurrence of incidents or accidents at the workplace, Article 28 of the convention stresses migrant workers' right and entitlement to receive immediate medical care, treatment, and benefit for the preservation of their health and life.

In addition, the International Covenant on Economic, Social, and Cultural Rights (ICESCR) recognizes the right of everyone, including migrant workers, to the enjoyment of the highest attainable standard of physical and mental health. It mentions that the States Parties are responsible to recognize the right of everyone to the enjoyment of just and favourable conditions of work which ensure safe and healthy working conditions. Furthermore, Article 


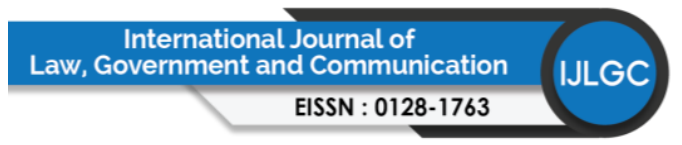

Volume 6 Issue 26 (December 2021) PP. 48-60

DOI 10.35631/IJLGC.626005

12 of the ICESCR underlines the importance of recognizing the right to health, which includes the right to healthy occupational and environmental conditions.

Besides, the right of everyone to occupational health and safety is also recognized under the ILO conventions and recommendations. According to ILO, it is estimated that nearly 270 million workers are victims of accidents at work and 160 million work-related diseases annually (International Labor Organization, 2020). The report also reveals that an average of six thousand workers dies every day due to work-related accidents and diseases, totaling more than 2.2 million work-related fatalities every year. The ILO also identified non-enforcement of labour legislation as the main reason that has resulted in denial of the right of workers to just and favourable conditions at work (United Nations, 2016). In line with its aims to promote rights at work, encourage decent employment opportunities, enhance social protection and strengthen dialogue on work-related issues, ILO has developed several conventions and recommendations that underline the critical importance of establishing safe and healthy working conditions and environment. Emphasizing that a safe condition of work is one of the core elements of the employment relationship and workers' protection, the ILO has introduced the Migration for Employment Convention, 1949 (Revised) (No. 97), the Migrant Workers (Supplementary Provisions) Convention, 1975 (No. 143) and their supplementary recommendations, Migration for Employment Recommendation (Revised), 1949 (No. 86), and Migrant Workers Recommendation, 1975 (No. 151), particularly for the protection of migrant workers. For example, Article 15 of the Migration for Employment Convention, 1949 (Revised) (No. 97) mentions the supervision of living and working conditions. It states the duty of states to make specific provisions for the supervision by the competent authority or duly authorized bodies of the territory of immigration of the living and working conditions, including hygienic conditions, to which the migrants are subject. In addition, the Migrant Workers Recommendation, 1975 (No. 151) mentions about the protection of the health of migrant workers. Article 20 states that all appropriate measures should be taken to prevent any special health risks to which migrant workers may be exposed. It further lists down various measures that should be taken to protect the safety of the migrant workers at the workplace. Among these measures are to ensure that migrant workers receive training and instruction in occupational safety and occupational hygiene in connection with their practical training or other work preparation, to provide them with information in their mother tongue or, in a language with which he is familiar, on the essential elements of laws and regulation and provisions of collective agreements concerning the protection of workers and the prevention of accidents as well as on safety regulations and procedures particular to the nature of the work ( Article 21), to take all possible measures so those migrant workers may fully understand instructions, warnings, symbols and other signs relating to safety and health hazards at work and to provide them with adequate training(Article 22).

In short, the right of migrant workers to occupational safety and health is recognized and guaranteed under various international instruments. The international instruments have laid down standards and the framework on occupational safety and health as a guideline to state parties. Acknowledging occupational safety and health as a fundamental aspect of the right to just and favorable conditions of work, the international instruments urge state parties to take necessary measures to ensure the highest attainable level of physical and mental health and safety of workers. Therefore, state parties have to formulate legal frameworks and policies at the national level for the protection of workers and the prevention of occupational incidents. 


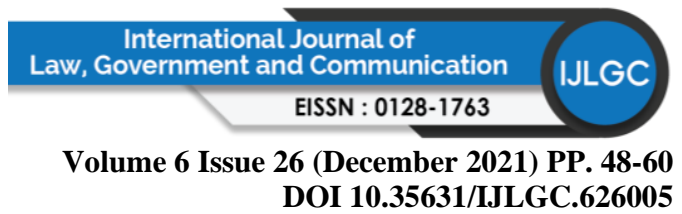

The States parties are expected to take all necessary measures and immediate preventative steps to prevent occupational incidents.

\section{Legal Position under Malaysian Law}

Similar to other countries, migrant workers in Malaysia are considered among the most vulnerable members of society. Basically, the government of Malaysia recognizes various rights of migrant workers, including the right to occupational health and safety. In order to protect these rights, the government of Malaysia has introduced various rules and regulations, and policies that govern matters relating to the occupational health and safety of migrant workers.

\section{Governing Statutes}

As far as Malaysian law is concerned, several statutes govern matters relating to the safety workplace and occupational health of migrant workers. Among relevant statutes are the employment Act 1955, the Industrial Relations Act 1967, the Trade Unions Act 1959, the Workmen's Compensation Act 1952, Occupational Safety and Health 1994, Factory and Machinery Act 1967.

The most important statute on this matter is the Occupational Safety and Health 1994(OSH). Before the OSH was introduced in 1994, there was no specific statute governing employees' occupational safety and health at workplaces ((Bakri, Mohd Zin, Mishan \& Mohammed, 2006). The absence of specific legislation had contributed to a high reported number of incidents relating to the safety and health of workers. To cater to this problem, the Malaysian government has introduced the OSH with the intention to foster a safe working environment. The OSH provides specific provisions governing the safety, health, and welfare of workers at the workplace. It aims to protect and prevent workers from hazards and risks arising out of the activities at work. The Act imposes several legal obligations on employers to prevent occupational incidents and accidents. For example, the Act states that employers are responsible to take necessary measures to ensure the safety, health, and welfare at work of all their employees. Employers are required to provide safe workplaces to all their employers. They are responsible to ensure that the systems at their workplaces pose no risk to the health of their employees. In the event there are any accidents, incidents, occupational poisoning, or occupational disease at the workplaces, the employers are required to immediately inform the occurrence to the nearest occupational safety and health office, without any delay.

Apart from the $\mathrm{OSH}$, there are other relevant statutes that provide provisions relating to the safety of workers. Among these statutes are as follows;

\section{The Employment Act 1955}

The Act governs the relationship between employers and employees. The Act specifies the rights, obligations, and responsibilities of both employers and employees. As regard to the protection of employees, the Act provides specific provisions relating to hours of work, rest day, wages, termination, allowance, termination benefits, lay off benefit benefits, overtime allowance, contribution to Employees Provident Fund (EPF), contribution to Social Security Organization (SOCSO), contribution to the Employee Insurance System Scheme and others. 


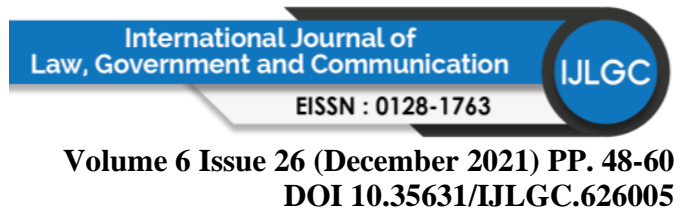

The Factory and Machinery Act (FMA) 1967

This Act governs safe workplaces at factories. It aims to provide the control of factories in respect of safety, health, and welfare of person therein, including workers. It contains provisions that regulate registration, inspection, and use of machinery which could pose risk and danger to the workers as well as the public. It stipulates that employees must be given adequate training on the handling of machinery and provided with adequate facilities for clothing, storage, water, first aid, and others (Section 25 and 26). It also imposes an obligation on the occupiers to inform the nearest inspector of the accidents and diseases (Section 31 and $32)$.

\section{The Employee' Social Security Act 1969}

The Act provides provisions pertaining to the protection of employees who suffer injuries at the workplace. The Act guarantees the right of employees who suffer from any occupational injuries, including occupational diseases and commuting accidents, to claim compensation and benefits. The Act provides that the workers' entitlement to claim for certain benefits, which include Medical benefit, disablement benefit, constant attendance allowance, dependants' benefit, funeral benefit, survivor's pension, and invalidity pension.

\section{The Workers' Compensation Act, 1952}

The Act provides for the payment of compensation to workmen for the injury suffered in the course of their employment. The Act requires the employers to ensure that their foreign workers are insured with the panel insurance company appointed under the Foreign Workers' Compensation Scheme by the Minister of Human Resources (Section 26 of the WCA 1952). Failure to comply with this requirement would render the employers liable to the punishment of a fine not more than RM20, 000.00 or jailed for not more than two years or both (Section 26(1) of the WCA 1952).

In short, the issue of occupational health and safety of migrant workers in Malaysia is governed by various statutes. These statutes provide relevant provisions concerning the occupational safety and health of migrant workers.

\section{High Reported Number of Occupational Accidents}

Despite legal protections in place, occupational safety and health issues involving migrant workers in Malaysia are reportedly widespread among workplaces that employ them. Various reports on the occurrence of occupational accidents among migrant workers indicate that the occupational health and safety of migrant workers is evidently lacking and requires better and comprehensive occupational safety and health laws. According to the Department of Occupational Health and Safety (DOSH), 6,793 occupational accidents were investigated in Malaysia in 2020 (DOSH, 2020). Out of that number, there were 193 deaths and 256 permanent disability cases recorded in that year. Selangor recorded the highest number of occupational accidents than any other state, with 1,537 cases reported. The statistic also disclosed that the national occupational accident rate was 2.40 per 1,000 workers, whereas the fatality rate was 4.24 per 100,000 workers in 2018. Below are Table I and Table II of the occupational incidents and national occupational accident and fatality rate recorded by DOSH. 
Volume 6 Issue 26 (December 2021) PP. 48-60 DOI 10.35631/IJLGC.626005

Table I: Accidents and Incidents Recorded By Dosh as of November 2020

\begin{tabular}{|l|l|l|l|l|}
\hline STATE & NPD & PD & DEATH & TOTAL \\
\hline JOHOR & 107 & 76 & 137 & 1175 \\
\hline KEDAH & 304 & 14 & 3 & 321 \\
\hline KELANTAN & 94 & 2 & 3 & 99 \\
\hline MELAKA & 310 & 5 & 8 & 323 \\
\hline NEGERI SEMBILAN & 400 & 13 & 3 & 416 \\
\hline PAHANG & 345 & 16 & 17 & 378 \\
\hline PERAK & 737 & 25 & 10 & 772 \\
\hline PERLIS & 22 & 0 & 0 & 22 \\
\hline PULAU PINANG & 717 & 18 & 13 & 748 \\
\hline SABAH & 204 & 20 & 20 & 244 \\
\hline SARAWAK & 353 & 17 & 25 & 395 \\
\hline SELANGOR & 1443 & 59 & 35 & 1537 \\
\hline TERENGGANU & 102 & 2 & 6 & 110 \\
\hline $\begin{array}{l}\text { WILAYAH PERSEKUTUAN } \\
\text { KUALA LUMPUR }\end{array}$ & 224 & 3 & 13 & 240 \\
\hline $\begin{array}{l}\text { WILAYAH PERSEKUTUAN } \\
\text { LABUAN }\end{array}$ & 12 & 1 & 0 & 13 \\
\hline TOTAL & $\mathbf{6 3 4 4}$ & $\mathbf{2 5 6}$ & $\mathbf{1 9 3}$ & $\mathbf{6 7 9 3}$ \\
\hline
\end{tabular}

Source: Department of Occupational Safety and Health, Ministry of Human Resources (2020)

Table II: National Occupational Accident \& Fatality Rate

\begin{tabular}{|l|l|l|l|l|l|l|}
\hline YEAR & $\mathbf{2 0 1 4}$ & $\mathbf{2 0 1 5}$ & $\mathbf{2 0 1 6}$ & $\mathbf{2 0 1 7}$ & $\mathbf{2 0 1 8}$ & $\mathbf{2 0 1 9}$ \\
\hline $\begin{array}{l}\text { Accident } \\
\text { Rate }\end{array}$ & 3.10 & 2.81 & 2.88 & 2.93 & 2.40 & 2.71 \\
\hline $\begin{array}{l}\text { Fatality } \\
\text { Rate }\end{array}$ & 4.21 & 4.84 & 4.84 & 4.90 & 4.14 & 2.83 \\
\hline
\end{tabular}

Source: Department of Occupational Safety and Health, Ministry of Human Resources

However, these reports merely provide the number of cases of occupational incidents as well as national occupational accidents and fatality rates involving both local and migrant workers. The reports do not provide detail about the reason and factors that have contributed to the incidents.

As regards to occupational incidents involving migrant workers, the statistic by DOSH reported that there were 2,760 claims made by the migrant workers in peninsula Malaysia who suffered multiple types of injuries due to occupational accidents in 2015 (DOSH, 2016). Out of that number, 650 related to temporary disability injuries, 1952 related permanent disability injuries, and 158 related to fatality cases. Those figures were based on cases where the migrant workers filed formal claims. The actual cases involving occupational accidents involving migrant workers were estimated higher than that as some cases were not reported, and no claim was filed by migrant workers, mainly on the ground that they were undocumented. They refused to file formal applications to avoid detention and investigation by the authorities due to their illegal status. 


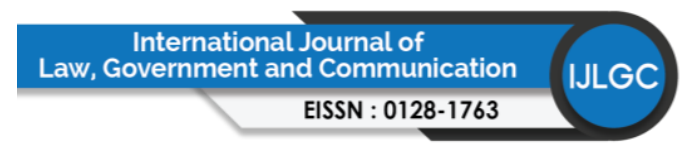

Volume 6 Issue 26 (December 2021) PP. 48-60 DOI 10.35631/IJLGC.626005

In addition, there was research conducted specifically on Nepalese migrant workers in Malaysia. Nepalese migrant workers are the second largest group of migrant workers in Malaysia, and the total number is estimated at 566,184. The research disclosed that a total of 1,562 Nepalese died of all causes in Malaysia between 2008 and 2015, which amounts to approximately four workers per week (Ethical Trading Initiative, 2019). Another report stated that the average death rate among Nepali migrant workers was one worker a day in recent years (Free Malaysia Today, 2017). The study further revealed that cardiovascular and suicide cases were the leading factors that led to the fatalities of Nepalese migrant workers (Pocock, N.S., Suphanchaimat, R., Chan, C.K., et al, 2018).

Based on the above discussion, it can be summarized that the number of occupational incidents is very high. The report also indicates that the cases of occupational incidents involving migrant workers are higher than in local workers. The high reported number of occupational incidents among the migrant workers in Malaysia has attracted serious concern from national and international groups on the occupational safety and health of migrant workers in Malaysia.

\section{Factors}

There are various factors identified as reasons that contributed to the high number of occupational accidents. Past research has revealed several reasons why migrant workers are vulnerable due to various factors such as language barrier, cultural barrier, lack of safety equipment, the inadequacy of and health education, the inadequacy of legal provisions, and others (Kim, M.J, et al, 2020). The hazardous working conditions and lack of safety equipment are identified as the main factors contributing to occupational incidents. It is well known that migrant workers in Malaysia primarily concentrate on 3D-jobs, such as outdoor construction, food service, agriculture, domestic work, and manufacturing. These jobs have been identified as having lower public policy standards and, therefore, exposing the workers to more significant injury and safety risks. Due to that reason, it shall be the duty of every employer and every self-employed person to ensure, so far as is practicable, the safety, care, and welfare at work of all his employees. Despite that fact, some employers fail to take necessary measures to ensure the safety of migrant workers. For example, the research disclosed that some employers in Malaysia failed to supply safety helmets or harness belts for their employees who are working on high-rise construction (Abd Rahim, N, Ng, H.K, Biggs, D \& Boots, K., 2014). The report also disclosed that some of them were asked to handle dangerous chemicals and equipment without being sufficiently given guidance on how to handle them (Ethical Trading Initiative. 2019). To make it worse, they are not equipped with sufficient safety equipment. In addition, there are instances where workers are required to operate hazardous equipment or handle dangerous chemicals, often without protective gear or guidance on how to protect them (Sahabat Wanita, 2019). Employees were also not educated on the precautionary measures that need to be taken when working in a dangerous situation.

In short, hazardous working conditions and lack of safety equipment are identified as the main reasons which contribute to the high number of occupational incidents in Malaysia. Therefore, it is important for the government to tackle these issues properly. The government needs to ensure that employers strictly comply with the laws and policies relating to occupational safety and health, especially relating to the safety of the workplace and safety equipment. 


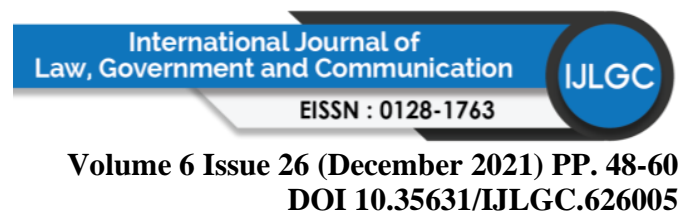

\section{Compensation Schemes Against Injuries}

Another issue relating to the protection of migrant workers in Malaysia is the adequacy of protection against injuries. The relevant statute relating to the protection of injuries of migrant workers is Workman Compensation Act 1952. The WCA 1952 was enacted to protect employees from any accidents, occurred in the course of employment or occupational diseases and temporary disablement. It aims to provide compensation to migrant workers who suffer from any type of damage in the workplace. The Act imposes an obligation on the Employers should be to make any payment of compensation to migrant workers such as medical or rehabilitation fees as stated in this Act (Article 4 of the WCA). However, in terms of remedies, it is important to highlight that the quantum and amount of remedies awarded to workers who suffer injuries resulting from accidents in the course of their employment are systematically unequal between local and migrant workers. Section 8 of the Act elaborates on the method of computing the compensation. Any worker who suffers from permanent disability shall be entitled to receive the compensation prescribed for such disability. The actual amount of compensation depends on his age. In case a worker is an adult who has completed the eighteenth year of his age, he shall entitle to a lump sum equal to sixty months' earnings or twenty-three thousand ringgit, whichever is the less. As for other adults, they shall be entitled to a lump sum equal to eighty-four months' earnings or twenty-three thousand ringgit, whichever is the less (Article 8(b) (i) \& (ii)). In addition, in the event a worker suffers from permanent partial disablement, he shall be entitled to such percentage of the compensation which would have been payable in the case of permanent total disablement as is proportionate to the permanent loss of earning capacity caused by the injury (Article 8 (c)). Where a worker suffers a temporary disablement, a half-monthly payment payable on the sixteenth day from the date of the disablement, and thereafter half-monthly during the disablement ordering a period of five years, whichever period is shorter of one hundred and sixty-five ringgit or an amount equal to one-third of his monthly earnings, whichever is the less (Article 8 (e)). In addition to that, the WCA requires every employer to ensure all their foreign workers are employed by the company under the Foreign Workers Compensation Scheme (FWCS) (Article26(2)). This section provides insurance coverage for the foreign worker against personal injury by accident or disease arising out of or in the course of employment, such as death from occupational disease or accident during working hours, death by accident whilst in the course of employment, funeral expenses, permanent total disablement, and temporary disablement, hospitalization \& medical expenses.

Previously, the schemes of compensation provided under WCA have been criticized by various parties. It was argued that it is too low and does not reflect the current value, compared to the scheme provided for local workers under Malaysia's Social Security Organization (SOCSO) (Abd Razak, M.F \& Nordin, R, 2018). It was also claimed that the compensation and insurance coverage provided under the WCA FWCS was insufficient to cover the actual hospitalization and medical charges incurred by the hospitals to migrant workers. As a result, the hospitalization and medical services become inaccessible to them.

Due to that, the government has introduced a new amendment relating to the protection and compensation of foreign workers. The government of Malaysia announced in December 2018 that coverage under the Employment Injury Scheme (EIS) under Malaysia's Social Security Organization (SOCSO) has been extended to foreign workers effective from 1 January 2019. Previously, the SOCSO only covers local workers who are Malaysian citizens. Pursuant to that, Malaysian employers are required to register their foreign workers and make required 


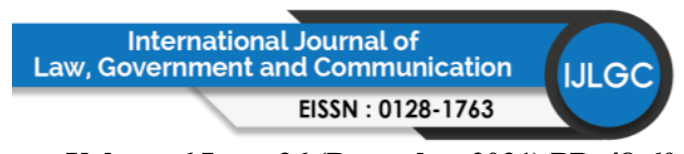

Volume 6 Issue 26 (December 2021) PP. 48-60 DOI 10.35631/IJLGC.626005

contributions to the SOCSO, with the first contributions due on 15 February 2019. The rate of contribution is $1.25 \%$ of the insured monthly wages and is to be paid by the employer. This newly introduced regulation made by the government of Malaysia has been lauded by various parties. It is in line with the requirements of the International Labour Organization's (ILO) Equality of Treatment (Accident Compensation) Convention 1925 (No. 19) and the Conference Committee on the Application of Standards. Consequently, this change has ensured that all foreign workers in Malaysia are equally entitled to employment injury schemes and benefits which are accorded to local employees.

\section{Findings and Recommendation}

There is no doubt that the government of Malaysia has introduced a legal framework to protect the rights and interests of migrant workers, including in the aspect of occupational health and safety. Reference to the existing laws indicates that various statutes govern the protection of the occupational health and safety of migrant workers. Among these statutes are Occupational Safety and Health 1994, the employment Act 1955, the Industrial Relations Act 1967, the Trade Unions Act 1959, the Workmen's Compensation Act 1952, Occupational Safety and Health 1994, Factory and Machinery Act 1967. These statutes contain extensive provisions relating to occupational health and safety of workers, such as the aspect of safety, health, welfare, working conditions, compensations, rights, obligations, and responsibilities of both employers and employees, medical benefits, and others. The protection of the occupational health and safety provided under these statutes are not only cover local workers but also extended to migrant workers. This policy and practice are commendable as it is in line with the requirements of the international standards on this matter.

Nevertheless, it is essential to note that there are still many rooms for improvement on this matter. Despite various efforts and actions taken by the government to protect the occupational health and safety of migrant workers, there is a growing concern over the effectiveness of the implementation of laws relating to the occupational health and safety of migrant workers in Malaysia. This is due to the statistical reports which reveal the high number of occupational incidents involving migrant workers in Malaysia. The reports indicate that migrant workers are more vulnerable to safety and health accidents than non-migrant workers. The reports also identify the issues of lack of enforcement of law and failure of the employers to strictly comply with the requirements relating to safety and health working condition are among the main factors that contribute to this problem. In view of that, it is crucial for the government of Malaysia to look into this matter and take prompt and appropriate measures to seriously address this prolonged issue. It is recommended that the government intensify law enforcement, particularly on the employers who persistently refuse and fail to provide safe and health working conditions to migrant workers. In addition, the punishment for non-compliance to the requirement to provide safe and healthy working conditions should be increased so that the employers will not take this matter for granted. Failure to do so would be detrimental to the image of the country in the eyes of international communities as it reflects the impression that the government condones unsafe working conditions by forcing migrant workers to work in unsafe, unhealthy, and dangerous conditions.

Apart from that, it is also suggested that the government focus on the enforcement of the right of migrant workers to join trade unions. While the current Malaysian law allows migrant workers to join trade unions, it is unfortunate that only a small number of them effectively exercise this right. The report reveals that only around 50,000 of the 2.2 million documented 


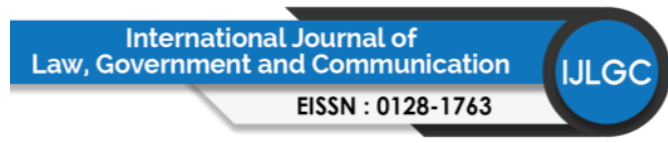

Volume 6 Issue 26 (December 2021) PP. 48-60 DOI 10.35631/IJLGC.626005

migrant workers in Malaysia are unionized (Free Malaysia Today, 2019). Due to a lack of enforcement by authorities, many migrant workers are often coerced and threatened by their employers from being unionized. The role of trade unions is vital in promoting the effective implementation of the occupational safety and health enforcement system. The trade union may stimulate the empowerment of migrant workers in upholding their right to occupational and healthy working conditions. The trade unions are proper channels to allow workers' active participation to discuss and negotiate with employers on all matters affecting their rights, including the issue of occupational safety and health.

Lastly, it is vital for the government of Malaysia to revise and improve the existing legal framework relating to the rights of migrant workers in Malaysia, including the right to occupational health and safety, in line with the international standards set by the international instruments. In revising or introducing any new policy and regulation relating to the improvement of occupational safety and health, it is recommended for the government to specifically ensure that it equally applicable to all workers, inclusive of migrant workers. Otherwise, migrant workers may be deprived of any benefit and advantage of the right of occupational safety and health. This measure is essential as it will ensure the rights of migrant workers on this are duly recognized and protected. This is in line with the fundamental principle of human right that emphasizes essential rights of a man is not derived from his nationality or state of origin but based upon attributes of his human personality.

\section{Conclusion}

The demand for migrant workers in Malaysia keeps on increasing and is expected to continue many years. As far as the right to occupational safety and health in this country is concerned, migrant workers often appear to be in the most vulnerable position. The emergence of new challenges relating to occupational safety and health, resulting from a combination of a deficient legal framework, poor governance system, lack of enforcement, insufficient resources and others, may pose severe problems to the government in handling this particular issue. Undoubtedly, comprehensive and transformative measures are necessary to face these challenges. It is indisputable fact that workers' rights to safety and health must be conceived as human rights. Therefore, it is the responsibility of the government of Malaysia to ensure this right is accorded to all workers, regardless of whether they are local or migrant. With the increasing trend in the employment of migrant workers in this country, it is crucial for the government to devise forward thinking legal framework and policies to address new emerging challenges and problems effectively. The effective execution of this prominent task requires the political will that strongly uphold the notion in the importance of workers' rights and undivided support from all stakeholders.

\section{References}

Abd Rahim, N., Ng, H.K., Biggs, D. \& Boots, K. (2014). Perception of Safety, Physical Working Conditions and Stress Between Malaysia and United Kingdom. International Journal of Business and Society. 15(2), p $321-338$.

Abd Razak, M.F. \& Nordin, R. (2018). The Right to Health: Discriminatory Treatment against Migrant Workers in Malaysia. JUUM, 23, 15 - 24. https://doi.org./10.17576/juum2018-23-03

Article 21

Article 22

Article 4 of the WCA 


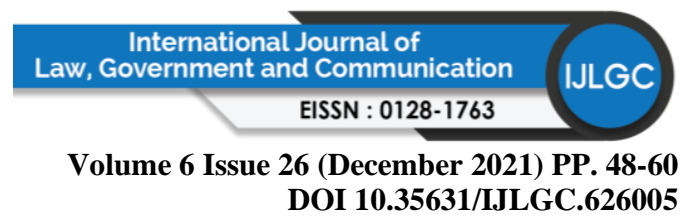

Article 8(b) (i) \& (ii)

Article 8 (c)

Article 8 (e)

Bakri, A., Zin, M., Misnan, M. S., \& Mohammed, A. H. (2006, September). Occupational Safety and Health (OSH) Management Systems: Towards Development of Safety and Health Culture. Paper presented at the 6th Asia-Pacific Structural Engineering and Construction Conference (ASPEC 2005), Kuala Lumpur, Malaysia. Retrieved from https://citeseerx.ist.psu.edu/viewdoc/download?doi=10.1.1.619.7629\&rep=rep1\&type $=$ pdf

Chung, N. (2019, December 27). Bosses Stopping Migrant Workers Joining Unions, Says MTUC. Free Malaysia Today. Retrieved from https://www.freemalaysiatoday.com/category/nation/2019/11/27/bosses-stoppingmigrant-workers-joining-unions-says-mtuc/

Department of Occupational Health and Safety. (2020). Occupational Accident Statistics by Sector Until November 2020. Retrieved from Department of Occupational Health and Safety website: https://www.dosh.gov.my/index.php/statistic-v/occupational-accidentstatistics/occupational-accident-statistic-2020

Department of Occupational Health and Safety. (2020) Malaysian Occupational Safety and Health Profile. Retrieved from Department of Occupational Health and Safety website: https://www.dosh.gov.my/index.php/ms/publication-sp-249/laporan-kajian-oshprofile/2638-ringkasan-laporan-chapter-3/file

Economic Planning Unit, Ministry of Economic Affairs. (2020). Retrieved from Ministry of Economic Affairs website: https://www.epu.gov.my/en/economicstatistics/population-and-labourforce

Ellis-Petersen, H. (2018, December 9). NHA Rubber Gloves Made in Malaysian Factories Linked with Forced Labour. The Guardian. Retrieved from https://www.theguardian.com/global-development/2018/dec/09/nhs-rubber-glovesmade-in-malaysian-factories-accused-of-forced-labour

Ethical Trading Initiative. (2019). Human Rights Due Diligence in Malaysia's Manufacturing Sector. $\quad$ Retrieved from https://www.ethicaltrade.org/sites/default/files/shared_resources/ETI\%20Malaysia\%2 OHRDD.pdf

International Organization for Migration. (2020). World Migration Report 2020. Retrieved from https://publications.iom.int/books/world-migration-report-2020

International Labour Organization. (2019). Safety and Health at the Heart of the Future of Work; building On 100 Years of Experience. Retrieved from International Labour Organization website: https://www.ilo.org/safework/events/safeday/WCMS_686645/lang--en/index.htm

International Labor Organization. (2020). Safety and Health at Work. Retrieved from International Labour Organization website: https://www.ilo.org/global/topics/safetyand-health-at-work/lang--en/index.htm

International Labour Organization (ILO), Migration for Employment Convention (Revised), C97, 1 July 1949, C97. Retrieved from https://www.refworld.org/docid/3ddb64057.html

International Labour Organization (ILO), Migrant Workers Recommendation, R151, 24 June 1975, R151. Retrieved from https://www.refworld.org/docid/3ddb6cd92.html 


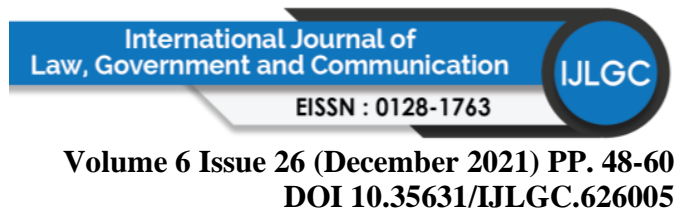

Kim, M.J., Son, K., Yum, S.K. \& Ahn, S. (2020). Analyzing the Risk of Safety Accidents: The Relative Risks of Migrant Workers in Construction Industry, Sustainability,12, 5430-5443. https://doi.org/10.3390/su12135430

Lee, H.A, \& Leng, K. H. (2018). Counting Migrant Workers in Malaysia: A Needlessly Persisting Conundrum. Retrieved from ISEAS-Yusof Ishak Institute website: https://www.iseas.edu.sg/images/pdf/ISEAS_Perspective_2018_25@50.pdf

Pocock, N.S., Suphanchaimat, R., Chan, C.K. et al. (2018). Reflections On Migrant and Refugee Health in Malaysia and The ASEAN Region. BMC Proc 12, 4-18. https://doi.org/10.1186/s12919-018-0100-6

Section 25 and 26.

Section 31 and 32.

Section 26 of the WCA 1952

Section 26(2)

Section 26(1) of the WCA 1952

United Nations, 'General Comment No. 23 (2016) On the Right to Just and Favorable Conditions of Work (Article 7 Of The International Covenant On Economic, Social And Cultural Rights).

UN Committee on Economic, Social and Cultural Rights (CESCR), General comment No. 23 (2016) on the right to just and favourable conditions of work (article 7 of the International Covenant on Economic, Social and Cultural Rights), 7 April 2016, E/C.12/GC/23. Retrieved from https://www.refworld.org/docid/5550a0b14.html

World Bank. (2019). Malaysia: Estimating the Number of Foreign Workers - A Report from The Labor Market Data For Monetary Policy Task. Retrieved from https://documents.worldbank.org/en/publication/documentsreports/documentdetail/953091562223517841/malaysia-estimating-the-number-offoreign-workers-a-report-from-the-labor-market-data-for-monetary-policy-task

Zuraini Ab Hamid, Z. \& Siti Fazilah Abdul Shukor, S.F. \& Ali Mohamed, A.A. (2018). Rights of Migrant Workers under Malaysian Employment Law. Journal of East Asia and International Law. 11(2), 359-360. https://doi.org/10.14330/jeail.2018.11.2.05

386 Nepalese migrant workers died here in 2016. (2017, January 21). Free Malaysia Today. Retrieved from http://www.freemalaysiatoday.com/category/nation/2017/01/21/report386-nepalese-migrant-workers-died-here-in-2016/ 